\title{
DETECTION AND PARTIAL CHARACTERIZATION OF AN ISOLATE OF Groundnut ringspot virus IN Solanum sessiliflorum
}

\author{
ALESSANDRA J. BOARI ${ }^{*}$, EUNIZE MACIEL-ZAMBOLIM ${ }^{2}$, DOUGLAS D. LAU², GAUS S. A. LIMA², \\ ELLIOT W. KITAJIMA ${ }^{3}$, SÉRGIO S. H. BROMMONSCHENKEL ${ }^{2} \&$ F. MURILO ZERBINI ${ }^{2}$
} ${ }^{1}$ Departamento de Fitopatologia, UFLA, Cx. Postal 37, Lavras, MG, 37200-000, e-mail: ajb@ @ufla.br; ${ }^{2}$ Departamento de
Fitopatologia/BIOAGRO, UFV, Viçosa, MG, 36571-000; ${ }^{3}$ NAP/MEPA, ESALQ/USP, Piracicaba, SP, 13480-000

(Accepted for publication on 15/03/2002)

Corresponding author: Alessandra de Jesus Boari

BOARI, A.J., MACIEL-ZAMBOLIM, E., LAU, D.D., LIMA, G.S.A, KITAJIMA, E.W., BROMMONSCHENKEL, S.H. \& ZERBINI, F.M. Detection and partial characterization of an isolate of Groundnut ringspot virus in Solanum sessiliflorum. Fitopatologia Brasileira 27:249-253. 2002.

\begin{abstract}
The cubiu (Solanum sessiliflorum) fruit, originating in the Amazon basin, is commonly used in that region for food, medicine, and cosmetics. In an experimental culture of cubiu, in order to evaluate its adaptation to conditions in the Northern region of the state of Rio de Janeiro, it was observed plants with mosaic symptoms. A cubiu plant was collected and analyzed to identify the etiological agent. After mechanical passage through a local lesion host, a host range test was performed. The virus induced chlorotic local lesions in Chenopodium quinoa, necrotic local lesions in Gomphrena globosa, mosaic in S. sessiliflorum, leaf and stem necrosis in tomato (Lycopersicon esculentum) 'Rutgers', mosaic and leaf distortion in Datura stramonium and Physalis floridana, and necrotic local lesions followed by systemic necrosis and plant death in four Nicotiana species. Electron microscopic observations of ultra thin sections from infected cubiu leaves

showed the presence of spheroidal, membrane-bound particles typical of tospovirus species. Analysis of the nucleocapsid protein from concentrated virus particles indicated the presence of a 28 $\mathrm{kDa}$ protein. RT-PCR was performed after total RNA extraction from infected IPA-6 tomato leaves. A fragment of approximately $0,8 \mathrm{kbp}$ corresponding to the $\mathrm{N}$ gene was amplified, cloned and sequenced. The $\mathrm{N}$ protein from the cubiu isolate was $95 \%$ homologous to the Groundnut ringspot virus (GRSV) protein, and no more than $85 \%$ homologous to those from Zucchini lethal chlorosis virus (ZLCV) and Chrysanthemun stem necrosis virus (CSNV), Tomato spotted wilt virus (TSWV), and Tomato chlorotic spot virus (TCSV). This is the first report of the occurrence of GRSV (or any other plant virus) in cubiu.

Additional keywords: Tospovirus, cubiu fruit, GRSV, occurrence.

\section{RESUMO}

\section{Detecção e caracterização parcial de um isolado de Groundnut ringspot virus em Solanum sessiliflorum}

O cubiu (Solanum sessiliflorum), originário da Amazônia, é um fruto utilizado como alimento, medicamento e cosmético. Em um plantio experimental de cubiu, para a avaliação da sua adaptação nas condições da região Norte do Estado do Rio de Janeiro, observouse plantas com sintomas de mosaico. Uma planta de cubiu foi coletada e analisada para a identificação do agente etiológico. Após a purificação biológica, o vírus foi inoculado via extrato foliar em uma série de plantas diferenciadoras. Foram observadas lesões locais cloróticas em Chenopodium quinoa, lesões locais necróticas em Gomphrena globosa, mosaico em S. sessiliflorum, necrose foliar e de caule em tomate (Lycopersicon esculentum) 'Rutgers' e mosaico e deformação foliar em Datura stramonium e Physalis floridana. O vírus ocasionou lesões locais necróticas e necrose sistêmica seguida

de morte de quatro espécies de Nicotiana. Em cortes ultra-finos de folhas de cubiu foram observadas partículas de formato circular envolvidas por membrana, típicas de tospovírus. A análise em SDSPAGE da proteína do nucleocapsídeo concentrada a partir de folhas de cubiu revelou uma banda com aproximadamente $28 \mathrm{kDa}$, valor esperado para tospovírus. Um fragmento de aproximadamente 0,8 bp correspondente ao gene $\mathrm{N}$ (proteína do nucleocapsídeo) foi amplificado por RT-PCR, clonado e seqüenciado. Foi constatada homologia de sequiência de aminoácidos de $95 \%$ entre a proteína $\mathrm{N}$ do isolado do cubiu e de Groundnut ringspot virus (GRSV). Para as demais espécies a homologia foi inferior a $85 \%$. Este é o primeiro relato da ocorrência natural do GRSV (ou qualquer outro vírus) em plantas de cubiu.
\end{abstract}

\section{INTRODUCTION}

The cubiu (Solanum sessiliflorum L.) fruit, which originated in West Amazon, has a high nutritional value and is used throughout the Amazon basin for food, medicine and cosmetics. The fruit can be consumed "in natura" or processed as juice or jelly, and is used to treat anemia and elevated levels of cholesterol, uric acid, and glucose in blood. Infusions prepared from leaves, shoots, and roots can be used to treat spider bites and to heal external wounds. As a cosmetic, the fruit juice can be used to shine hair (Silva et al., 1988).

Diseases caused by tospoviruses cause great losses in agriculture throughout the world (Goldbach \& Kuo, 1996). In Brazil, these viruses are among those that cause the greatest 
economical losses in vegetable and ornamental crops (Pozzer et al., 1996).

The genus Tospovirus, family Bunyaviridae, includes viruses with spheroidal particles measuring 80 to $110 \mathrm{~nm}$ in diameter. Particles are limited by a lipid bilayer envelope containing glycoproteins (German et al., 1992). Inside the envelope, besides the viral polymerase, three genomic RNAs are found, and are designated based on their relative size: $\mathrm{L}$ RNA, M RNA, and S RNA. The L RNA, of negative polarity, contains one open reading frame (ORF) that encodes the viral polymerase (De Haan et al., 1991). The M RNA, of ambisense polarity, contains two ORFs responsible for the production of the non-structural protein NSm and the envelope glycoproteins G1/G2 (Kormelink et al., 1992). The S RNA, also ambisense, is responsible for production of the nonstructural protein NSs and the nucleocapsid (N) protein (De Haan et al., 1990). Tospoviruses are naturally transmitted by thrips, in a propagative fashion (Ullman et al., 1993; Wijkamp et al., 1993).

Several species of the genus Tospovirus have been identified based on host range, specificity of transmission by different thrips species, and nucleotide sequence of the $N$ gene, such as Tomato spotted wilt virus (TSWV), Groundnut ringspot virus (GRSV), Tomato chlorotic spot virus (TCSV) (Ávila et al., 1993b), Impatiens necrotic spot virus (INSV) (Law et al., 1991), Groundnut bud necrosis virus (GBNV) (Heinze et al., 1995), Watermelon silver mottle virus (WSMV) (Yeh \& Chang, 1995), Watermelon bud necrosis virus (WBNV) (Jain et al., 1998), Iris yellow spot virus (IYSV) (Cortês et al., 1998), Peanut bud necrosis virus (PBNV) (Satyanarayana et al., 1996), Peanut yellow spot virus (PYSV) (Satyanarayana et al., 1998), Zucchini lethal chlorosis virus (ZLCV) (Bezerra et al., 1999), and Chrysanthemum stem necrosis virus (CSNV) (Bezerra et al., 1999).

In Brazil, the presence of viruses in cubiu plants had not been reported to date. The objective of this work was to identify and partially charactere of a viral isolate from cubiu plants by host range, electron microscopy, analysis of the nucleocapsid protein and sequencing of the $N$ gene.

\section{MATERIALS AND METHODS}

\section{Viral isolate}

The characterized isolate was obtained from cubiu plant located at an experimental plot at Universidade Estadual do Norte Fluminense (UENF), Campos dos Goytacazes (RJ). Plants showed mosaic (Figure 1) and spotted fruits.

The isolate was biologically purified by single lesion passage through Chenopodium quinoa Willd. [using ice-cold $0.02 \mathrm{M}$ potassium phosphate buffer, $\mathrm{pH}$ 7.2, containing $0,1 \%(\mathrm{w} / \mathrm{v})$ sodium sulphite] and further sapinoculation, using the same buffer, to Datura stramonium L., and Physalis floridana Rybd. plants. The biologically pure isolate was maintained in D. stramonium by successive sap inoculations and stored as dried leaf material at $-80^{\circ} \mathrm{C}$.

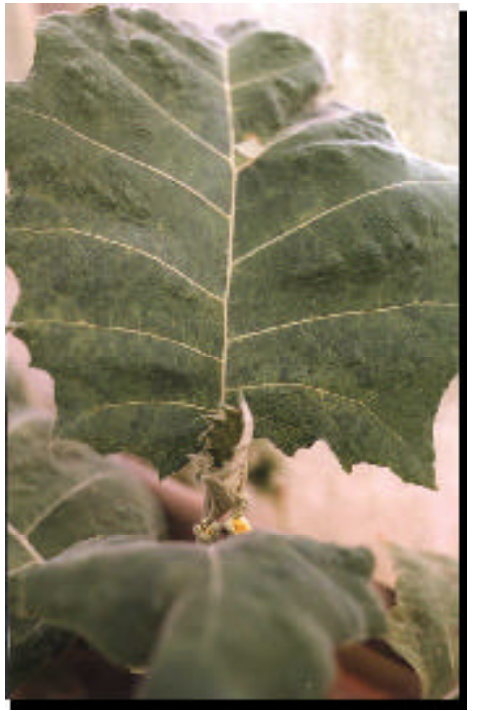

FIG. 1 - Cubiu (Solanum sessiliflorum) plant showing mosaic symptoms.

\section{Host range experiment}

The virus was inoculated into a series of indicator plants: Chenopodium quinoa Willd., Lycopersicon esculentum L. 'Rutgers', S. sessiliflorum, Gomphrena globosa L., Datura stramonium L., P. floridana, Nicotiana benthamiana Domin., $N$. glutinosa L., N. rustica L., N. debney Domin., N. tabacum L. 'White Burley', 'Havana 425', 'TNN', 'Xanthi', and 'Samsum', Capsicum annuum L. 'Baby Ac-119', and Cucurbita pepo L. 'Caserta'

Eight plants from each species were used, four inoculated and four mock-inoculated with buffer alone. Plants were sap-inoculated as described above, maintained in a greenhouse and evaluated for 30 days post-inoculation.

Electrophoresis (SDS-PAGE) of the nucleocapsid protein Partially purified preparations of the viral isolate were obtained as described by Lane (1992), from $2 \mathrm{~g}$ of cubiu leaves, seven days after inoculation. The nucleocapsid protein was analyzed by SDS-PAGE using a MiniProtean II apparatus (BioRad, EUA), according to manufacturer's instructions.

\section{Electron microscopy}

Fragments of leaves from infected plants were fixed in modified Karnovksky solution $(2.5 \%$ v/v glutaraldehyde, $2.5 \% \mathrm{v} / \mathrm{v}$ paraformaldehyde, $0.001 \mathrm{M} \mathrm{CaCl}_{2}$ in $0.05 \mathrm{M}$

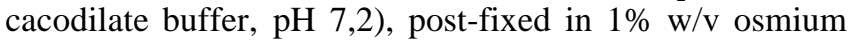
tetroxide in the same buffer, stained with $0.5 \% \mathrm{w} / \mathrm{v}$ uranyl acetate, dehydrated in acetone and blocked in Spurr resin. Ultra thin sections were obtained with a diamond razor in a Reichert Ultracut $\mathrm{T}$ ultramicrotome, stained with uranyl acetate and lead citrate and examined in a Zeiss EM900 transmission electron microscope.

\section{Total RNA extraction}

Tomato plants, cv. IPA-6, infected with the cubiu 
Detection and partial characterization of an isolate of Groundnut ringspot...

isolate were used for total RNA extraction, using the RNeasy kit (Qiagen, EUA), according to manufacturer's instructions.

\section{Cloning of the $N$ gene}

A cDNA was synthesized from total RNA using the "SuperScript Preamplification System for First Strand cDNA Synthesis" kit (Life Technologies). The RT-PCR reaction was prepared according to manufacturer's instructions, using the oligonucleotide primers NGRSVR (5'-CCC TGC AGA GCT CTC ATG CAA CAC CAG CAA TCT TG-3'), which anneals at the 3' end of the $N$ gene (capsid protein) and contains a SacI site (underlined), and NGRSVF (5'-GAT CTA AGG ATC CAC CAT GTC TAA GGT CAA GCT C-3'), which anneals at the start codon of the $N$ gene and contains a $B a m \mathrm{H}$ I site (underlined).

The reaction consisted of 30 cycles with the following steps: $95^{\circ} \mathrm{C}$ for $1 \mathrm{~min}, 50^{\circ} \mathrm{C}$ for $2 \mathrm{~min}$ and $72^{\circ} \mathrm{C}$ for $1 \mathrm{~min}$, with a final extension at $72{ }^{\circ} \mathrm{C}$ for $7 \mathrm{~min}$. Results were evaluated by agarose gel electrophoresis $(0,9 \% \mathrm{w} / \mathrm{v}$ agarose in $1 \times$ TAE buffer), staining with ethidium bromide and observation under UV light.

The amplified fragment was purified with phenol/ chloroform, precipitated with 1/10 vols of $3 \mathrm{M}$ sodium acetate, $\mathrm{pH} 5.2$ and 2.5 vols of absolute ethanol, and digested with $\mathrm{Sac}$ I and $\mathrm{BamH} \mathrm{I}$. The cleaved fragment was ligated to the pBluescriptKS+ vector ( $\mathrm{pKS}+$, Stratagene, EUA) and transformed into Escherichia coli DH5 $\alpha$. Cloning was confirmed by plasmid extraction followed by digestion with BamH I and Sac I. The clone pCubioN1 was completely sequenced on both strands using the chain termination method with a Sequenase 2.0 kit (United States Biochemicals, EUA), according to manufacturer's instructions.

Sequences were compared with those from other tospoviruses available at GenBank. Comparisons were carried out using the software package from the Genetics Computer Group of the University of Wisconsin (Devereux et al., 1984) and the Clustal W program (Thompson et al., 1994).

\section{RESULTS}

\section{Host range experiment}

Chlorotic local lesions were observed in C. quinoa, necrotic local lesions in G. globosa, leaf and stem necrosis in L. esculentum 'Rutgers', mosaic in S. sessiliflorum, and mosaic and leaf distortion in D. stramonium and P. floridana. Leaf chlorosis and vein necrosis followed by plant death were observed in $N$. benthamiana. The virus induced the formation of necrotic local lesions and systemic necrosis followed by plant death in N. glutinosa, N. debney, N. rustica, and $N$. tabacum 'White Burley', 'Havana 425', 'TNN', 'Xanthi', and 'Samsum'. These symptoms are typically induced in these hosts by several tospoviruses. No symptoms were observed on C. annuum 'Baby Ac-119' and C. pepo 'Caserta'.

\section{Electron microscopy}

Spheroidal, membrane-bound particles with approximately $90 \mathrm{~nm}$ of diameter, typical of the tospoviruses, were observed in ultra thin sections prepared from cubiu leaves (Figure 2).

\section{Analysis of the nucleocapsid protein}

SDS-PAGE analysis of the nucleocapsid $(\mathrm{N})$ protein, obtained from concentrated virions from cubiu leaves, revealed the presence of a band with a relative molecular mass of approximately $28 \mathrm{kDa}$, the expected value for the tospovirus nucleocapsid protein (data not shown).

\section{Sequencing of the $N$ gene}

A DNA fragment with approximately 800 base pairs (bp), corresponding to the nucleocapsid $(N)$ gene, was RTPCR-amplified from infected cubiu plant, cloned into $\mathrm{pKS}+$ and completely sequenced. The $N$ gene from the cubiu isolate has 777 nucleotides, with the potential to code for a 258 amino acid protein. Comparison of the deduced amino acid sequence of the $\mathrm{N}$ protein from the cubiu isolate with those from other tospoviruses revealed an homology of $95 \%$ with GRSV, and below $85 \%$ with the remaining species (Table 1), confirming the identity of the cubiu isolate as GRSV.

\section{DISCUSSION}

The genus Tospovirus comprises species of great economic importance, due to the severity of the diseases mainly in vegetable and ornamental crops (Pozzer et al., 1996). Among the tospoviruses described to date, TSWV, TCSV, and GRSV have already been reported in different

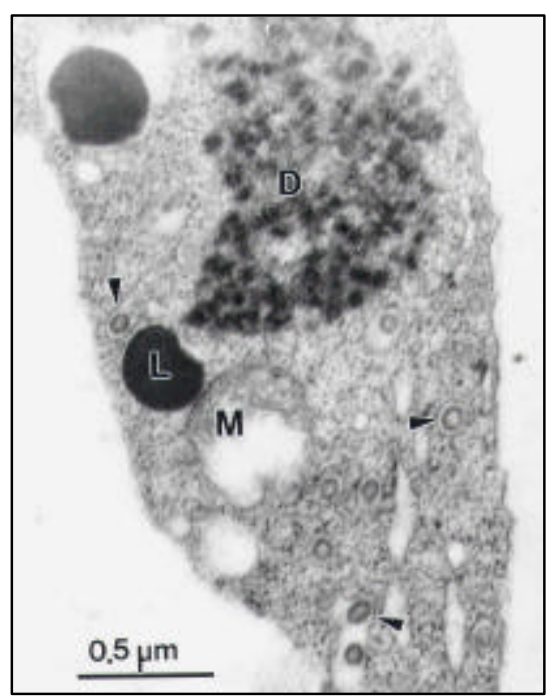

FIG. 2 - Electron micrograph of ultra thin sections of cubiu (Solanum sessiliflorum) leaves infected by Groundnut ringspot virus (GRSV-Cb). The arrows indicate virions inside endoplasmic reticulum elements. Electron-dense masses (D) indicate an accumulation of nucleocapsids. L- lipid; Mmitochondria. 
TABLE 1 - Percent amino acid homology among the nucleocapsid proteins of the cubiu (Solanum sessiliflorum) isolate of Groundnut ringspot virus, (GRSV-Cb) and other Tospovirus species

\begin{tabular}{lcccccccc}
\hline Species* & TSWV & TCSV & GRSV & INSV & ZLCV & CSNV & IYSV & GRSV -Cb \\
\hline TSWV & 100 & 77 & 78 & 55 & 72 & 75 & 35 & 79 \\
TCSV & & 100 & 81 & 53 & 73 & 72 & 32 & 84 \\
GRSV & & & 100 & 54 & 75 & 73 & 33 & 95 \\
INSV & & & & 100 & 52 & 54 & 30 & 58 \\
ZLCV & & & & & 100 & 80 & 32 & 77 \\
CSNV & & & & & & 100 & 32 & 74 \\
IYSV & & & & & & & 100 & 36 \\
GRSV-Cb & & & & & & & 100 \\
\hline
\end{tabular}

* Tomato spotted wilt virus (TSWV), isolate CNPH9 (GenBank accession number D00645); Tomato chlorotic spot virus (TCSV), isolate Br03 (S54325); Groundnut ringspot virus (GRSV), isolate SA05 (S54327); Impatiens necrotic spot virus (INSV) (X66972); Zucchini lethal chlorosis virus (ZLCV) (AF067069); Chrysanthemum stem necrosis virus (CSNV) (AF067068); Iris yellow spot virus (IYSV)(AF067070), GRSV-Cb, GRSV isolate from cubiu (AF251271).

regions of Brazil (Nagata et al., 1995). Additionally, three new species have been recently described in Brazil: Iris yellow spot virus (IYSV) (Pozzer \& Bezerra, 1999) Chrysanthemum stem necrosis virus (CSNV), and Zucchini lethal chlorosis virus (ZLCV) (Bezerra et al., 1999), making Brazil the country with the highest diversity of tospoviruses. This diversity reflects the adaptive capacity of these viruses, which can occupy different ecological niches, and their consequent speciation. In addition, some species like TSWV, TCSV, GRSV, and CSNV have extremely wide host ranges. Thus, it is not surprising that new studies find other species, and new hosts for previously described virus species.

In the present work, the etiological agent of a disease in cubiu was identified as GRSV. Results from host range and electron microscopy initially suggested the presence of a tospovirus. Although symptoms induced in indicator plants are still used as an aid in the identification of tospovirus, this does not seem to be an adequate method considering the overlapp in the host range of some species (Ávila et al., 1993a). It is also common to observe symptom attenuation after successive mechanical passages, due to the appearance of defective-interfering (DI) RNAs (Resende et al., 1991). The isolate was definitively identified as GRSV by sequencing the $N$ gene.

The cubiu plants, multiplied from seeds originating in the Amazon basin, were being tested for their adaptation to the conditions of Northern Rio de Janeiro. The primary inoculum source probably consisted of wild hosts of GRSV, present at the vicinity of the experimental plot at the Universidade Estadual do Norte Fluminense campus. To this date, GRSV had not been reported in the state of Rio de Janeiro, and no virus had ever been reported in cubiu. The results presented here demonstrate how important of preliminary studies are for the introduction of plant species to new geographical regions. In this case, previously existing pathogens, which did not have the opportunity to co-evolve with the introduced species, cause serious damage or even make commercial production impossible. Although the losses caused by GRSV in cubiu plants have not been estimated, the potential of damage by tospoviruses is high, pointing out the need for a careful evaluation of the consequences of GRSV (and possibly other tospoviruses) infection in cubiu.

\section{LITERATURE CITED}

ÁVILA, A.C., DE HAAN, P., KORMELINK, R., RESENDE, R.O., GOLDBACH, R.W. \& PETERS, D. Classification of tospoviruses based on the phylogeny of nucleocapsid gene sequences. Journal of General Virology 74:153-159. 1993b.

ÁVILA, A.C., DE HAAN, P., SMEETS, M.L.L., RESENDE, R.O., KITAJIMA, E.W., GOLDBACH, R.W. \& PETERS, D. Distinct levels of relationships between tospovirus isolates. Archives of Virology 128:211-227. 1993a.

BEZERRA, I.C., RESENDE, R.O., POZZER, L., NAGATA, T., KORMELINK, R. \& ÁVILA, A.C. Increase of tospoviral diversity in Brazil with the identification of two new tospovirus species, one from chrysanthemum and one from zucchini. Phytopathology 89:823-830. 1999.

CORTÊS, I., LIVIERATOS, I.C., DERKS, A., PETERS, D. \& KORMELINK, R. Molecular and serologycal characterization of iris yellow spot virus, a new and distinct tospovirus species. Phytopahtology 88:1276-1282. 1998.

DE HAAN, P., KORMELINK, R., RESENDE, R.O., VAN POELWIJK, F., PETERS, D. \& GOLDBACH, R. Tomato spotted wilt virus L RNA encodes a putative RNA polimerase. Journal of General Virology 71:2207-2216. 1991.

DE HAAN, P., WAGEMAKERS, L., PETERS, D. \& GOLDBACH, R. The S RNA segment of tomato spotted wilt virus has an ambisense character. Journal of General Virology 71:10011007. 1990.

DEVEREUX, J., HAEBERLI, P. \& SMITHIES, O. A comprehensive set of sequence analyses programs for the VAX. Nucleic Acids Research 12:387-395. 1984

GERMAN, T.L., ULLMAN, D.E. \& MOYER, J.W. Tospoviruses: diagnosis, molecular biology, phylogeny, and vector relationships. Annual Review of Phytopathology 30:315-348. 1992.

GOLDBACH, R. \& KUO, G. International Symposium on Tospoviruses and Thrips of Floral and Vegetable Crops. Acta Horticulturae 431:21-26. 1996.

HEINZE, C., MAISS, E., ADAM, G. \& CASPER, R. The complete nucleotide sequence of the S RNA of a new Tospovirus species, representing serogroup IV. Phytopathology 85:683690. 1995.

JAIN, R.K., PAPPU, H.R., PAPPU, S.S., KRISHNA-REDDY, M. \& VANI, A. Watermelon bud necrosis tospovirus is a distinct virus species belonging to a serogroup IV. Archives of Virology 143:1637-1644. 1998.

KORMELINK, R., DE HAAN, P., MEURS, C., PETERS, D. \& GOLDBACH, R. The nucleotide sequence of the M RNA segment of tomato spotted wilt virus, a bunyavirus with two ambisense RNA segments. Journal of General Virology 73:2795-2804. 1992.

LANE, L. A general method for detecting plant viruses. In: Maramorosch, K. (Ed.) Plant diseases of viral, viroid, mycoplasma and uncertain origin. New Delhi. Oxford \& IBH Publishing. 1992. pp.1-15.

LAW, M.D., SPECK, J. \& MOYER, J.W. Nucleotide sequence of 
Detection and partial characterization of an isolate of Groundnut ringspot...

the 3'-non coding region and $\mathrm{N}$ gene of the S RNA of a serologically distinct tospovirus. Journal of General Virology 72:2596-2601. 1991

NAGATA, T., ÁVILA, A.C., TAVARES, P.C.M., BARBOSA, C.J., JULIATTI, F.C. \& KITAJIMA, E.W. Occurrence of different tospoviruses species in six states of Brazil. Fitopatologia Brasileira 20:90-95. 1995.

POZZER, L. \& BEZERRA, I.C. Characterization of a tospovirus isolate of iris yellow spot virus associated with a disease in onion fields in Brazil. Plant Disease 83:345-350. 1999.

POZZER, L. RESENDE, R.O., LIMA, M.I., KITAJIMA, E., GIORDANO, L.B. \& ÁVILA, A.C. Tospovirus: uma visão atualizada. Revisão Anual de Patologia de Plantas 4:95-148. 1996.

RESENDE, R.O., DE HAAN, P., ÁVILA, A.C., KITAJIMA, E.W., KORMELINK, R., GOLDBACH, R. \& PETERS, D. Generation of envelope and defective intefering RNA mutants of tomato spotted wilt virus by mechanical passage. Journal of General Virology 72:2375-2383. 1991.

SATYANARAYANA, T., GOWDA, S., REDDY, K.L., MITCHELL, S.E., DAWSON, W.O. \& REDDY, D.V.R. Peanut yellow spot virus is a member of a new serogroup of the Tospovirus genus based on small (S) RNA sequence and organization. Archives of Virology 143:353-364. 1998.

SATYANARAYANA, T., MITCHELL, S.E., REDDY, D.V.R., KRESOVICH, S., JARRET, R., NAIDU, R.A., GOWDA, S.
\& DEMSKI, J.W. Peanut bud necrosis tospovirus S RNA: complete nucleotide sequence, genome organization and homology to other tospoviruses. Archives of Virology 141:8598. 1996.

SILVA, D.F., CLEMENT, C.R. \& NODA, H. Relação entre descritores e populações de cubiu (Solanum sessiliflorum) avaliadas na Amazônia Central. Revista Brasileira de Fruticultura 10:67-70. 1988.

THOMPSON, J.D., HIGGINS, D.G. \& GIBSON, T.J. CLUSTAL $\mathrm{W}$ : Improving the sensitivity of progressive multiple sequence alignment through sequence weighting, position-specific gap penalties and weight matrix choice. Nucleic Acid Research 22:4673-4680. 1994.

ULLMAN, D.E., GERMAN, T. L., SHERWOOD, J.L., WESTCOL, D.M. \& CUSTER, D. M. Tospoviral replication in insect vector cells: Immunocytochemical evidence that the non-structural protein encoded by the S RNA of tomato spotted wilt tospovirus is present in thrips vector cells. Phytopathology 83:456-463. 1993.

WIJKAMP, I., VAN LENT, J., KORMELINK, R., GOLDBACH, R. \& PETERS, D. Multiplication of tomato spotted wilt virus in its insect vetor, Frankliniella occidentalis. Journal of General Virology 74:341-349. 1993.

YEH, S.D. \& CHANG, T.F. Nucleotide sequence of the $\mathrm{N}$ gene of the watermelon silver mottle virus, a proposed new member of the genus Tospovirus. Phytopathology 85:58-64. 1995. 